\section{ラットにおけるおからテンペの タンパク質の消化性}

\section{松 尾 眞砂子*}

\author{
Digestibility of Okara-tempe \\ Protein in Rats \\ Masako Matsuo* \\ * Gifu Women's University, 80-Taromaru, \\ Gifu 501-25
}

\begin{abstract}
Okara-tempe (OT) is fermented okara (OC) by Rhizopus oligosporus (a fungus to make Tempe). In this paper, the effects of fermentation on the digestibility of $O C$ protein were studied by using rats. By comparing $O T$ with $O C$ in respect of free amino acid content and the distribution of molecular weight of proteins, OT contained more free amino acids and lower molecular weight proteins than OC. The results suggest that some parts of OT proteins are decomposed into low molecular weight substances by the fermentation of OC. On optical micrograph of the digestive residue from rats fed on OT or OC diets which contained OT or OC proteins as the only source, the proteins in the cecum residue of OT diet were not detected appreciably, but those of $O C$ diet were clearly observed. In the feces residue of OT or OC diets, any protein was not observed. It is presumed that both proteins of OT and OC will be completely digested, and OT protein will be digested easier than $O C$ protein in rats.
\end{abstract}

Key words : okara, okara tempe, protein, digestibility

(Received Feb. 5, 1996)

大豆粕であるおから（以下 OC と略す）は乾重量で $57 \%$ の食物䋖維と $20 \%$ のタンパク質を含んでいる゙。. OCの食糧化をはかるために，OCをRhizopus oligosporus (テンペ菌) で発醳させてお加らテンペ（以 下OTと略す）を調製すると OC 緎維が部分分解され て, 総織維は $57 \%$ 加 50\% に減少し，遊離糖は $12 \%$ 加
ら $19 \%$ に増加する”． OC は消化の良くない食品として 敬遠されているが, OTでは織維が分解されているので, タンパク質の消化性も向上している可能性がある. 著者 は，先にOTタンパク質は OC タンパク質より酸可溶性 窒素や遊離アミノ酸の総量が多く，タンパク質の人工消 化率あ向上していることを報告しだ”か，in vivoにおけ る消化性にっいては不明である。

本報告では, in vivoにおけるタンパク質の消化性を 知るために，OC とOTの遊離了ミノ酸量やタンパク質 の分子量分布を測定し比較した。 また，OCやOTを唯 一のタンパク質源とする飼料でラットを飼育し，盲腸内 消化残渣に残存するタンパク質を光学顕微鏡で観察し， タンパク質の消化性を推定した。

\section{1. 実験方法}

おから（OC）はビーンフラワー（みすずコーポレー ション）を用いた．おからテンペ（OT）は水分を $75 \%$ に調製した OC に $R$. oligosporus の胞子を接種し，通気 用小穴のあいたポリエチレン製袋に厚さ約 $15 \mathrm{~mm}$ に詰 め， $30^{\circ} \mathrm{C}$ で 24 時間培養して調製した。遊離了ミノ酸は HPLC で加水分解形として分析した. カラムはShimpack ISC-07/S $1504 \mathrm{Na}(4.0 \phi \times 15 \mathrm{~cm})$ を用い, Ex. $348 \mathrm{~nm}, E \mathrm{E} .450 \mathrm{~nm}$ で検出した。 タンパク質は大久保の 方法 ${ }^{2)}$ に従い，試料に $1 \%$ SDS を含む $8 \mathrm{M}$ 尿素液 $(\mathrm{pH}$ 7.8）を加えて脱気し， $40^{\circ} \mathrm{C}$ で 2 時間擋找して抽出した。 抽出液は脱イオン水を用いて透析し， pHを 4.5 に調整 して生じた沈殿を涷結乾燥して集めた. OT の酸沈殿夕 ンパク質はHPLCによりゲル漟過を行った。カカラムは Shim-pack Diol-150, $7.9 \mathrm{~mm} \phi \times 50 \mathrm{~cm}$, 移動相は 0.2

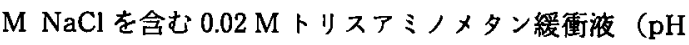
7.0）を用い， $0.8 \mathrm{ml} / \mathrm{min}, 280 \mathrm{~nm}$ で検出した。

実験動物には 5 週齢の Wistar/ST 系雄性ラット（日 本エスエルシー株式会社）10 匹を用い，OCまたはOT を $50 \%$,コーン油 $5 \%$, 塩混合 $4 \%$, ビタ ミン混合 $1 \%$,

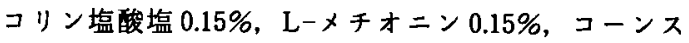
ターチ $39.7 \%$ からなる飼料を自由摂取させた。 OC 飼料 とOT眗料はそれぞれタンパク質を $9.5 \%$ と $10.5 \%$ ，総 䋐維を $27 \%$ と $25 \%$ 含んでいた. ラットは 2 週間飼育し た後，屠殺し，飼料タンパク質の消化状態を調べため に盲腸や小腸内消化残渣と蕒を $1.5 \%$ の酢酸を含む $95 \%$ エタノールで洗浄して消化酵素や腸内細菌を除去した 後, 残存タンパク質をクーマシー・ブリリアントブルー R250で染色した ${ }^{4}$. 同様にして染色した眗料と消化残渣 の染色試料を光学顕微鏡下で镜察し, 染色タンパク質量

* 岐阜女子大学（干501-25 岐阜市太郎丸 80） 
からタンパク質の消化性を推定した。

2. 実験結果及び考察

(1) 遊離アミノ酸量

OC とOTの遊離了ミノ酸量を测定し, Table 1 に示 す. 本実験ではアミノ酸標準液に加水分解形のみを用い たのでアスパラギン，グルタミン，トリプトファンは定 量できなかった，OCにはアルギニン以外の遊離アミ， 酸は極く微量存在するか，すしくは全く検出されなかっ たが，OTではいずれのアミ，酸も検出可能な量に增加 し，紷アミノ酸量として 14 倍に増加した.このような遊 離アミノ酸量の増加は, OTでは発酵により OC タンパ ク質の一部が分解されていることを示唆している.

(2) タンパク質の分子量

OTやOCの酸沈殿タンパク質をゲル淿過して分子量 の分布を調べたすのを Fig. 1 に示す. OT タンパク質は OC タンパク質に比へ，分子量 300000 以上の区分の吸 光度が少なく, 10000〜300000 の区分の吸光度が多かっ た.すなわち，OTタンパク質は OC タンパク質より分 子量の小さいタンパク質を多く含んでいると考えられ る. OTタンパク質は OC タンパク質より人工消化率が

Table 1 Free amino acid contents of Okara and Okara-tempe

\begin{tabular}{lcc}
\hline \hline & \multicolumn{2}{c}{ Amino Acid $(\mu \mathrm{g} /$ dry $\mathrm{g})$} \\
\cline { 2 - 3 } & Okara & Okara-tempe \\
\hline Aspartic acid & ND & 81.6 \\
Threonine & ND & 268.0 \\
Serine & 0.66 & 53.8 \\
Glutamic acid & 0.74 & 130.8 \\
Proline & ND & 31.9 \\
Glycine & 0.30 & 26.7 \\
Alanine & ND & 70.6 \\
Cysteine & ND & 0.7 \\
Valine & ND & 60.9 \\
Methionine & ND & 33.6 \\
Isoleucine & ND & 24.8 \\
Leucine & ND & 64.5 \\
Tyrosine & ND & 52.2 \\
Phenylalanine & ND & 21.0 \\
Histidine & 1.40 & 61.9 \\
Lysine & ND & 13.2 \\
Arginine & 3.83 & 28.2 \\
\hline Total & 6.93 & 970.4 \\
\hline ND Not & & \\
\hline
\end{tabular}

ND : Not detected.

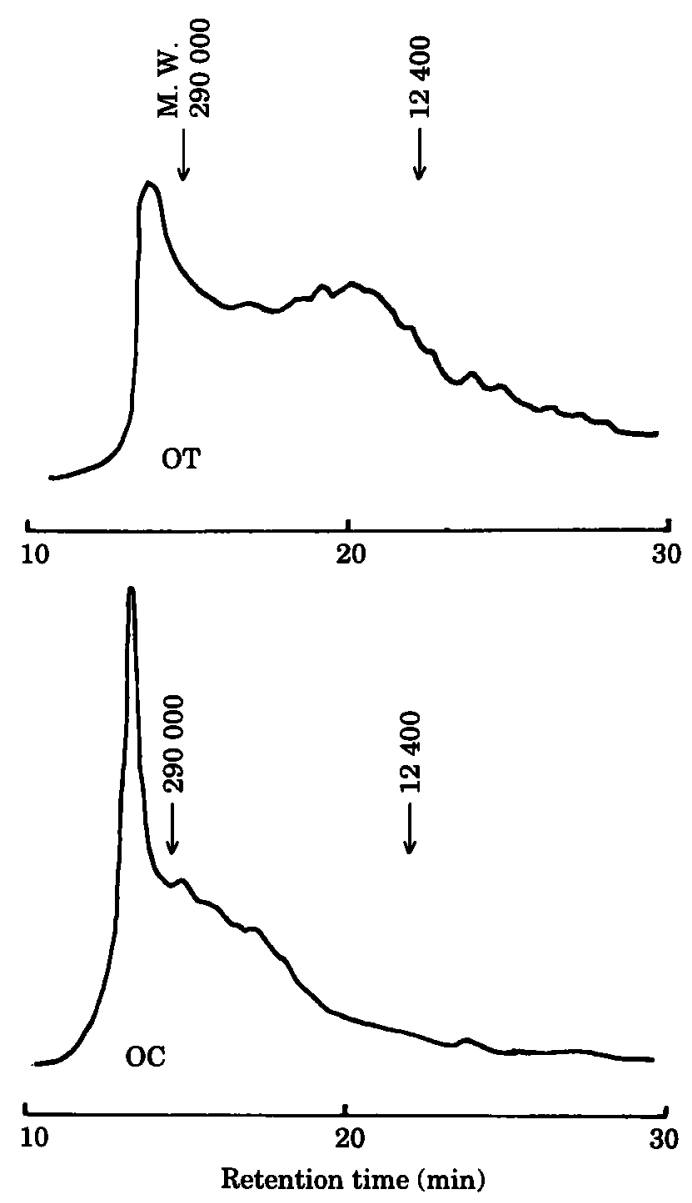

Fig. 1 Gel permeation chromatograms of proteins of okara and okara-tempe

column : Shim-pack Diol-150 $\quad(7.9 \mathrm{~mm} \times 500$

$\mathrm{mm}$ ). Mobile phase : $0.02 \mathrm{M}$

Tris $\cdot \mathrm{HCl}-0.2 \mathrm{M} \mathrm{NaCl}(\mathrm{pH} 7.0)$. Flow rate $: 0.8$ $\mathrm{ml} / \mathrm{min}$.

Abbreviations : OC, Okara ; OT, Okara-tempe ; M.W., Molecular weight.

高い1) 事実と考え合わせると，OCタンパク質に比べ OT タンパク質は消化が容易であることが推測された.

(3) タンパク質の消化性

OT OC を唯一のタンパク質源とした飼料をラット に 2 週間投与すると摂食量は $114 \pm 5 \mathrm{~g}$ と $118 \pm 3 \mathrm{~g}$, 体 重増加量は $73 \pm 4 \mathrm{~g}$ と $73 \pm 7 \mathrm{~g}$ で両飼料は同等の成長効 果を示した. ラットの消化残渣を回収し，残存する未消 化タンパク質を染色して光学顕微鏡像を観察した，その 典型的な写真を Fig， 2 に示す。染色剂として使用した 


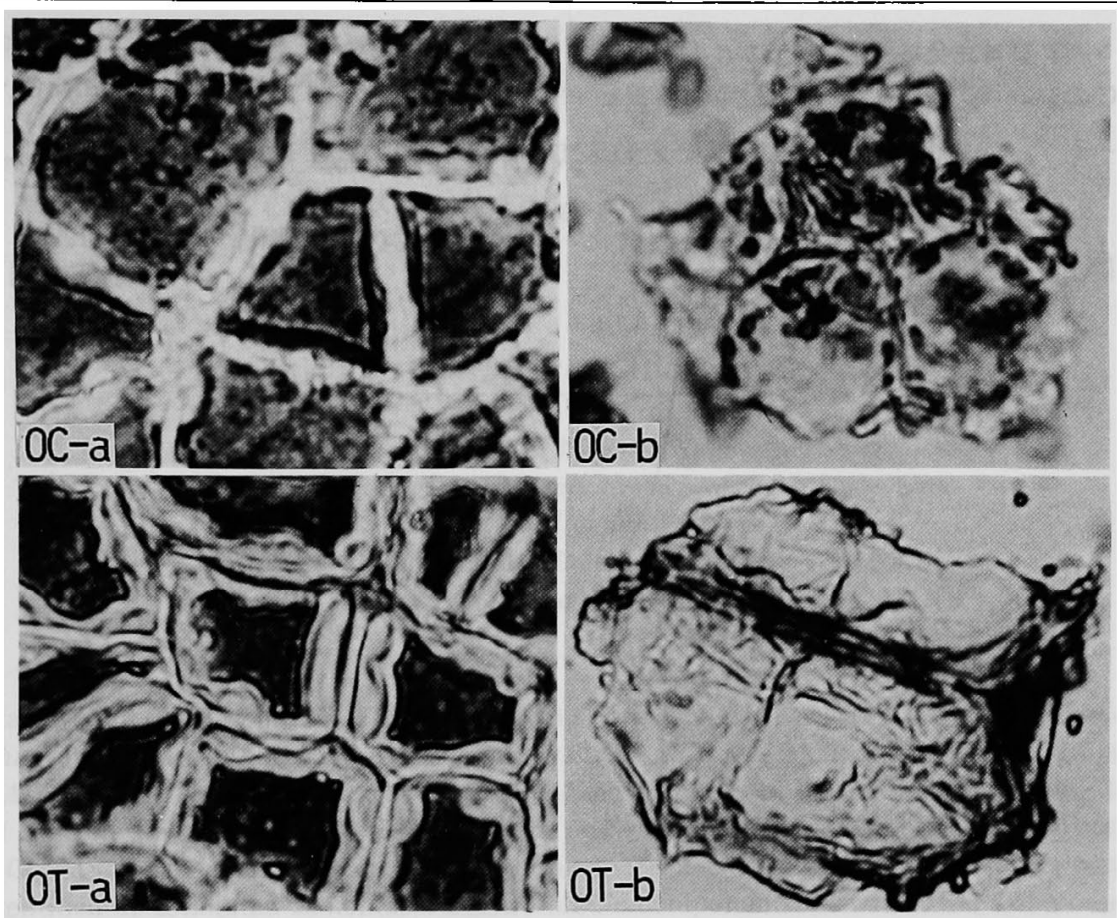

Fig. 2 Optical micrographs of digestive residues of okara and okara-tempe in rats

OC, okara; OT, okara-tempe; a, sample in diet; b, digestive residue in cecum. Only OC or OT was used as a dietary protein source. The digestive residues of $\mathrm{OC}$ and $\mathrm{OT}$ which were collected from the cecum, were stained by Coomassie Brilliant Blue-R250 ( $\times 1000)$.

クーマシー・ブリリアントブルー R 250 はタンパク質の 電気泳動後の位置確認に頻用されている高感度のタンパ ク質染色剂で，微量タンパク質の存在が確認できる試薬 である.したがって，写真の黒い部分はタンパク質の分 布域を示す． 飼料中のタンパク質分布を比較するとOT では OCより分布域が狭く，テンペ菌によりタンパク質 が利用されていることが示唆された．盲腸内消化残渣で は OC, OT のいずれすタンパク質の分布域が激減し，夕 ンパク質の消化に基づく溶出が示唆された。 また，残存 タンパク質の存在は OC の消化残渣では明確に確認でき たが， OTの消化牫渣では不明瞭であった，本研究では タンパク質を定量しなかったが, 多数のタンパク質染色 像を比較し, OT と OC の消化残渣に明確な差を認めた. OT の小腸内消化残渣と䔬中消化残渣ではタンパク質は 全く検出されなかった．OCの小腸内消化残渣では極く 微量のタンパク質が確認できたが，粪中消化残渣では夕 ンパク質は全く検出されなかった.この結果から OT夕 ンパク質は OC タンパク質より容易に消化，吸収され，
最終的には両タンパク質とも完全に利用されることが推 測された. OTではOCの繊維が部分分解され1), 構造が 著しく変形している5．タンパク質の低分子化 (Fig. 1) に加え，䄉維の分解もタンパク質の消化吸収性を高める 要因になっているのであろう.

\section{3. 要 約}

おから（OC）をテンぺ菌で発酵させたおからテンペ (OT) では，タンパク質の消化性が発酵によりどのよう な影響を受けるかを調べた，遊離アミ/酸量やタンパク 質の分子量分布を比較すると，OTにはOCより遊離了 ミ／酸や低分子領域のタンパク質が多かった。この結果 から，OTでは発酵によりタンパク質の一部が分解され ていることが示唆された．また，OCやOTを唯一の夕 ンパク質源とする飼料でラットを飼育し, 消化残渣を光 学顕微鏡で観察するとOT の盲腸内消化残渣ではタンパ ク質の存在が不明瞭であったが，OCの盲腸内消化残渣 ではタンパク質を明確に確認できた．䔬中消化残渣では 両飼料ともタンパク質は全く確認できなかった．した 
がって、両タンパク質は完全に利用されるが，OTの夕 ンパク質はOCのタンパク質より容易に消化されること が推察された。

\section{文献}

1）松尾䢐仯子：篓食誌，42，173 (1989).

2）大久保一良：食品開発，19，11（1984）.
3）佐々木康人・玉井洋介・林 洋一 - 淕田正二郎 · 藤尾高志・小笠原武雄・江頭祐嘉合・真田宏夫 · 綾野雄幸 : 栄食誌, 44，461（1991）。

4) BRadFold, M.M.: Anal. Biochem., 72, 248 (1976).

5）松尾埧砂子: 農化，69，163(1995).

(平成 8 年 2 月 5 日受理) 